\title{
The Koidu Vertical Pit - Sierra Leone
}

\author{
Joubert, J.S.C. ${ }^{1}$, Freeman, L.A. ${ }^{2}$, Terbrugge, P.J. ${ }^{3}$ \& Venter J. $^{3}$ \\ ${ }^{1}$ Koidu Holdings S.A., Freetown, Sierra Leone \\ ${ }^{2}$ BSG Resources (Pty) Ltd, Illovo, South Africa \\ ${ }^{3}$ SRK Consulting (Pty) Ltd, Illovo, South Africa
}

\section{Introduction}

Koidu Holdings S.A. is wholly owned by BSG Resources (Pty) Ltd and holds the rights to the Koidu Kimberlite Project in the Kono District within the historically productive diamond fields of Sierra Leone.

The Koidu Kimberlite Project is situated within the Tankoro Chiefdom of the Kono District in the Eastern Province of Sierra Leone, approximately $2 \mathrm{~km}$ south of the district capital, Koidu, and approximately $330 \mathrm{~km}$ east of Freetown, the capital city.

When the Company returned to the Koidu Kimberlite Project Mining Lease Area after the war ended in 2002, No. 1 Pipe was flooded and was being used by the local community. After dewatering of the $30 \mathrm{~m}$ deep open pit excavation made by Sierra Leone Selection Trust and the National Diamond Mining Company in the 1970s and 1980s, removal of the remaining silt and mud commenced. No. 1 Pipe was mined by conventional open pit methods from January 2004 to May 2004, after which mining shifted to No. 2 Pipe. During this time and having assessed the scale of the disruption to the community and the impact of blasting, the Company considered either switching to standard underground mining methods or attempting the innovative and pioneering vertical pit mining technique on the No. 1 Pipe. Continuing with the open pit at No. 1 Pipe was ruled out because, apart from the negative social and environmental impacts posed by the close proximity to the town, the small size of the pipe would have limited the maximum depth of mining below the existing pit floor to a further $80 \mathrm{~m}(120 \mathrm{~m}$ below surface) before the high stripping ratio would have made the deposit uneconomical to mine. At that stage, insufficient information regarding grade and diamond value was known to justify establishing an underground mining operation from the outset. The vertical pit option appeared to hold the most merit, requiring limited capital investment for establishment, and minimizing the social impacts and environmental footprint of the operation. SRK Consulting was approached to determine whether vertical pit mining would be appropriate from a geotechnical perspective and, if so, to undertake a vertical pit design for No. 1 Pipe.
Vertical pit mining is a relatively new mining technique which has been successfully implemented only once before, at the Nyala chrome deposit in Zimbabwe in the late 1990s (Redford \& Terbrugge, 2000). By supporting the vertical sidewalls of the pit by means of cable anchors, rock bolts, wire mesh and wetcrete, a large open air shaft roughly the size of the ore body is established. We have refined the technique and shown that it can be employed successfully, even in very difficult environments. Having attained a depth of $126 \mathrm{~m}$ from surface and $74 \mathrm{~m}$ from the headgear collar established at the level of the open pit floor, the Koidu vertical pit essentially represents the largest diameter "shaft" to have reached such depths.

\section{Geology}

Sierra Leone is situated on the Man Craton of the Southern West African Shield. The Koidu Kimberlite Project Mining Lease Area contains two kimberlite pipes (No. 1 Pipe and No. 2 Pipe), four dyke zones (Dyke Zones A, B, C and D), the Ring Structure, a small blow on Dyke Zone A and another blow on Dyke Zone B. The country rock in the Koidu area is granodiorite gneiss, containing metamorphic inclusions of amphibolite, ultrabasic schists, quartzites and granulites, among others. The kimberlite dyke systems at Koidu have strike orientations of between $070^{\circ}$ and $074^{\circ}$ and are restricted to the area between two parallel regional scale $010^{\circ}$ trending faults.

\section{Vertical Pit Design}

The design of the vertical pit excavation was carried out using various calculation approaches to ensure design integrity. The material parameters were obtained by back analysis of the existing highwall at the No. 1 Pipe, excavated during previous mining attempts, and using the Hoek-Brown failure criteria based on the laboratory tests and core logs. The design calculations comprised limit equilibrium, 2dimensional and 3-dimensional numerical modeling. The results obtained from each of these methods were ranked according to stability and a final design decision made. 


\section{Implementation}

Following the positive outcome from SRK's geotechnical analysis and vertical pit design study, the decision was taken to proceed with the development of a vertical pit at the Koidu No. 1 Pipe (Fig. 1 \& 2). With the steep sided open pit already at $52 \mathrm{~m}$ below surface at the time, establishing the vertical pit collar at that level meant that the preparation work and time required for the development of the collar infrastructure and erection of the headgear and winder was significantly reduced. Nevertheless, certain modifications to the open pit profile were necessary to provide sufficient working space and suitable access for the ore transport vehicles.

Based on the available geological information, the maximum extent of the kimberlite pipe at depth was projected to surface, forming the perimeter of the vertical pit. The limited drillhole data suggested that the pipe plunged gently towards the south and the design work had taken that into account. However, during collar preparation, evidence was found of kimberlite infiltrating fractures in the country rock at the intended location of the headgear.

Further investigations revealed a bulge in the pipe, typical of the irregularities commonly observed in the root zone of kimberlite pipes. The headgear had to be moved to a new location, requiring substantial additional waste stripping. The enlarged perimeter of the vertical pit made reworking of the geotechnical analyses and design work necessary. The increase in the pit floor area from approximately $3,480 \mathrm{~m}^{2}$ to $4,388 \mathrm{~m}^{2}$ impacted negatively on the final design depth, reducing the maximum depth from $180 \mathrm{~m}$ to approximately $100 \mathrm{~m}$.

\section{Lateral Support}

Based on the analysis and other design work, the following support elements were recommended:

- Wetcrete with a compressive strength of $30 \mathrm{MPa}$ and minimum thickness of $75 \mathrm{~mm}$;

- Weldmesh with wire diameter of $4 \mathrm{~mm}$ and aperture size of $150 \mathrm{~mm}$;

- Fully bonded grouted dowels with an ultimate tensile strength of 14 tonnes at a 1.5 by $1.5 \mathrm{~m}$ spacing;

- $20 \mathrm{~m}$ long cable anchors tensioned to 40 tonnes at a $5 \mathrm{~m}$ by $7 \mathrm{~m}$ spacing. The fixed end was $5 \mathrm{~m}$ long leaving $15 \mathrm{~m}$ free for tensioning which was grouted after some time. Provision had to be made to decrease the spacing to $5 \mathrm{~m}$ by $5 \mathrm{~m}$ for $30 \%$ of the time as well as for 30 $\%$ of the anchors to have a $40 \mathrm{~m}$ length as required.
During mining it became necessary to install $40 \mathrm{~m}$ anchors near the collar elevation to prevent a kinematic mechanism developing beneath the hoist platform. The actual anchor system used had to be varied several times during mining due to difficulties sourcing the required wire rope but the total support effort remained constant. Difficulties were also experienced with a fully grouted fixed end as this caused delays to the mining schedule. Experiments with mechanical expansion shells were only partly successful as they failed to grip in some instances. Doubts were also expressed about their reliability due to the generally low confinement of the rock mass near surface.

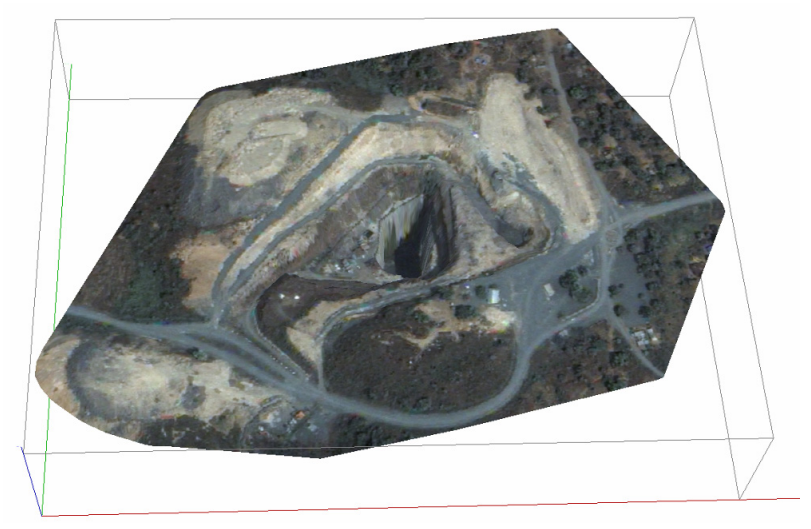

Fig. 1 Satellite image of the Koidu No. 1 Pipe vertical pit draped over the 3D topographic surface.

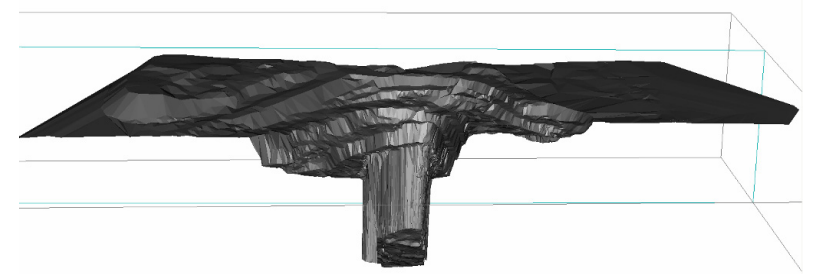

Fig. 2 E-W slice through the Koidu No. 1 Pipe vertical pit, showing the narrow benches of the open pit above the vertical pit collar and the vertical sidewalls forming a large shaft on the kimberlite pipe.

\section{Planning}

Whilst the LOM plan and annual depletion plan formed the basis of the monthly planning, a number of issues had to be taken into consideration during the detailed monthly planning sessions. One of the most important of these was the restriction on the time and frequency of blasting. All households within the $250 \mathrm{~m}$ blast envelope had to be evacuated before each blast, requiring a well coordinated effort between the Company and local authorities to ensure the safety of the community and the protection of property during the time before and after each blast. The Company reached an agreement with the Government and the local community that blasting would be limited to twice per week, taking place between $15 \mathrm{H} 00$ and $16 \mathrm{H} 00$. 
Careful and detailed planning was required to ensure that the sequencing of the various activities within the vertical pit were coordinated with the permitted blasting schedule. Furthermore, adherence to the schedule was paramount, because slippage in any one of the activities would impact on those down the line.

For example, the support installation, including the drilling of holes for cable anchors and rock bolts had to be completed before the meshing and wetcreting could be applied, all of which had to be completed before the next scheduled blast in a particular area. The cycle time for installing one cable anchor was four days starting from the moment the anchor was installed into the hole until it was tensioned and signed off. The planning had to allow for this standing time and focus activities in other parts of the pit while ensuring that the drill rigs and support teams were working from a safe and comfortable footwall. The support activities and mining production activities, therefore, had to be carefully synchronized to ensure continuous operation of the vertical pit.

Another critical factor in the mine planning was sustaining the production target of at least 26,000 tonnes ROM ore to keep the 50 tonne per hour DMS processing plant operating at optimum capacity. Hoisting capacity was limited to 1,728 tonnes per day, with the average hoisting achieved being approximately 1,400 tonnes per day. Downtime necessary for hoist examinations and maintenance every 10,000 tonnes or at least once per week had to be accounted for in the planning, as well as the loss of shifts due to blast preparation.

Other factors that had to be considered in the planning included the maintenance of a sump for drainage and dewatering purposes, as well as creating and maintaining a free face for optimal blasting results. In cases where problems encountered during the month set the schedule out of synch, these activities had to be incorporated into the work programme for the following month.

\section{Economics}

Among the deciding factors in the selection of the vertical pit mining method for the exploitation of the Koidu No. 1 Pipe was the cost of establishing the vertical pit and the associated ongoing operating costs. A trade-off study between the conventional open pit option and the vertical pit option was undertaken, comparing capital requirements, operating costs and the time frame in which each of the options could be realistically implemented.

In order to maintain optimum processing capacity, the earthmoving fleet required to achieve the waste mining targets for open pit mining of No. 1 Pipe would have included 6 ADTs, 2 excavators, 1 dozer, 5 drill rigs and service infrastructure, at a total cost at the time of US\$ 4.3 million.
In comparison, the capital expenditure for the vertical pit was US\$ 3.1 million, which included a smaller earthmoving fleet (4 ADTs, 2 excavators, 1 dozer, 2 drill rigs), as well as the construction of the headgear and winder foundations and the purchase of generators and support equipment over and above what would have been required for conventional open pit mining. The capital expenditure required for the vertical pit equipment and development, whilst being higher than for the open pit, was well below what would have been called for if underground mining had been the only other viable option.

On a cost per tonne basis, vertical pit mining (US\$ 15.82 ) is more expensive than hard rock open pit mining in Sierra Leone (US\$ 2.50). However, the benefit is realized when considering the negligible waste mining involved in vertical pit mining versus open pit mining. The stripping ratio for the vertical pit is only 0.65 whereas the stripping ratio for the open pit would have increased from 6.2 on the first cut to 13.6 on the final cut.

From a timing perspective, the initial work required for the establishment of the vertical pit collar and infrastructure was estimated to take only two months. However, the relocation of the headgear and the subsequent additional stripping delayed the work programme by six months. In October 2005, the hoist and winder were commissioned and the transition to full-scale vertical pit mining was made.

Vertical pit mining has been shown to be an economically viable alternative to open pit and underground mining methods on small kimberlite pipes. The factors critical to the successful implementation of this technique are the following:

- The geometry of the orebody must be known. Variances in size and shape can be problematic particularly with the development of overhangs;

- An imperative for the design is a full geotechnical appreciation of the host rock and the groundwater conditions;

- Economic factors - required depletion rate, cost per tonne, revenue per tonne;

- Design specifications should be strictly adhered to with efficient quality control; and

- Ongoing geotechnical input including mapping and logging is a pre-requisite for success.

\section{References}

Redford, M.S. and Terbrugge, P.J. (2000): Vertical Pit Mining - A Novel Alternative to Open Pit or Underground Methods for Mining of Appropriate Massive Shallow Orebodies. MassMin 2000.

Hoek, E. Carranza-Torres, C. and Corkum, B. (2002): HoekBrown failure Criterion. www.rocscience.com. 